\title{
The Role of Rachid Ghannouchi On Democratization In Tunisia After Ben Ali Regime
}

\author{
Cindi Riyanika $^{1}$, Muhammad Luthfi ${ }^{2}$, Mulawarman Hannase ${ }^{3}$ \\ $\left\{\right.$ 2‥luthfiz009@gmail.com, ${ }^{3}$ muhamadsyauqillah@ui.ac.id $\}$ \\ ${ }^{1,2,3}$ School of Strategic and Global Studies, Universitas Indonesia, Indonesia
}

\begin{abstract}
This research describes Rachid Ghannouchi's role in democratization in Tunisia after the Ben Ali regime, including in bridging the Islamists and secularists in Tunisia. This discussion is interesting because Tunisia is a secular country but when the 2011 election in Tunisia was won by the Islamic party of Al-Nahdah leading by Rachid Ghannouchi. In addition, the research on the role of Rachid Ghannouchi in democratization in Tunisia after the Ben Ali regime in detail is still limited. This study uses leadership theory. Leadership theory focuses on concepts based on experience which means that leadership can be found in a person from many practices or exercises. The concept of leadership is a fundamental component in analyzing processes and dynamics within the organization. This research provides an illustration of how Rachid Ghannouchi's role and efforts in democratization in Tunisia after the Arab Spring especially after the fall of the Ben Ali regime include the Cross-Party Partnership \& Coalition-Building. This study uses qualitative research and descriptive analysis methods.
\end{abstract}

Keywords: Rachid Ghannouchi, Democratization, Tunisia, Ben Ali Regime.

\section{INTRODUCTION}

Tunisia is one of the countries in the Middle East region which became the first country "spring" began. Spring is always associated with "renewal", because that is the upheaval in a number of countries in the Middle East referred to as "Spring" or "Arab Spring". The hope of Arab Spring is a renewal that is driven by the power of the people. Actually "Spring" is not only happening in the Middle East, but also initially occurred in parts of Europe which at that time the Middle East was not affected by the existence of "Spring" over there (Kuncahyono, 2013:1). Suddenly many parties were surprised by the "Spring" in the Middle East and North Africa region. The arrival of the "Spring" or better known as the Arab Spring dropped one by one an authoritarian regime, a regime that did a lot of corruption, a kleptocracy regime that had no concern for its people, and a regime that had stood for more than 10 years.

The early Arab Spring took place in Sidi Bouzid, a small town about 300 kilometers south of Tunisia (Kuncahyono, 2013:2). In the small town, the story of a vegetable and fruit trader named Mohamed Bouazizi inspired people in several Arab countries from the North African region to the Middle East region on mainland Asia. According to Kuncahyono (2013: 3) 
things that made him famous were not his achievements as a trader but his courage in taking extreme decisions as an expression of disappointment and resistance to the regime in power at the time.

On Friday, December 17, 2010, Mohamed Bouazizi stood in front of the local government building and flushed his body with gasoline and burned his body (Fraihat, 2016:58). Mohamed Bouazizi is a 26-year-old youth who had a tertiary education up to the baccalaureate level and sold vegetables because he did not get a job (Kuncahyono, 2013:3).

The action of Mohamed Bouazizi caused political upheaval in Tunisia which toppled the Ben Ali regime, this event spread to Egypt. Aarts (2012: 1) explains that in Egypt, popular revolutions succeeded in overthrowing Mubarak's government. Similarly in Libya, the antiGaddafi movement held armed resistance. Not only that, the resistance made by the people in the Middle East and North Africa region extends in Sudan, Yemen and Bahrain (Kuncahyono, 2013:5-6).

The political turmoil that occurred was not born of a single factor. Poverty, economic inequality, unemployment, repressive policies, and authoritarianism are important factors that mark these changes. The weeks after the dramatic Bouazizi action, Tunisia's political map changed drastically. The dictatorial regime that ruled for approximately 23 years withdrew from the government replaced by a new leadership system that supported the direction of changes in the country's socio-political, North African and world. However, the transition to the Tunisian revolution did not last long like other Middle Eastern countries. On January 14, 2011, 10 days after Bouazizi's death, Ben Ali finally exiled to Saudi Arabia(Ramahan, 2012:6).

After the fall of Ben Ali, Rachid Ghannouchi returned to Tunisia and revived the Annahdah party (Tamimi, 2015:54). In the general election on October 2011, Annahdah campaigned as an Islamic party. This is contrary to secular Tunisia so the victory of AlNahdah is an interesting and unexpected phenomenon for many parties. On the side of party supporters, the victory was considered a balance of modernity and Islam. However, for secularists in Tunisia, this is a threat with the return of religious politics which is considered to damage secular traditions in Tunisia (Jebnoun, 2014:9-10). In the eyes of the community, Annahdlah's victory was not a threat but was considered a new hope. For the Tunisian community in general, the main concern in the Annahdah program is human rights, women's rights and social welfare which includes the economy, education, and freedom in gathering (Brym dan Andersen, 2016:262).

The Tunisian people received the "branding" of political Islam brought by Rachid Ghannouchi. This happened because Rachid Ghannouchi captured the thought of young Tunisians who thought that the situation was a wealth in the name of justice and there would be employment opportunities. In addition, Rachid Ghannouchi had thoughts and estimates that the success of the new leadership in Tunisia should include the active role of the younger generation and provide the freedom to believe and express and then unite them in an open system of political contestation (Kartini, 2016:82-83). By involving young people, providing opportunities for women and understanding the character of Tunisia including efforts to bridge Islamists and secularists, Rachid Ghannouchi is considered to have a role in the transition to democracy in Tunisia after the Arab Spring.

On the other hand, Rachid Ghannouchi was an accomplished thinker, Islamic intellectual and politician known as a democratic fighter and activist in contemporary Islamic political movements. Rachid Ghannouchi proved himself able to mediate in bridging the secularists and Islamists in Tunisia after the Ben Ali administration. In Jebnoun's interview (2014: 17) 
what he did was to establish cooperation with the opposition and deliberation in the internal An-Nahdah in particular and the political elites in Tunisia.

The figure of Rachid Ghannouchi was born on June 22, 1941 in a small village called Hamma located in the southeastern province of Qabis. Ghannouchi was born and grew up in a religious and traditional family. Ghannouchi is the youngest child or the last child of ten brothers and sisters. His father was named Sheikh Muhammad, a religious figure in the village of Hamma and a person who memorized the Koran. Ghannouchi's father was not educated but had extensive knowledge and became a mufti and priest. Ghannouchi grew up in his father's care directly including memorizing the Koran. Besides having a biological mother, Ghannouchi also had another mother because Ghannouchi's father had more than one wife. Ghannouchi has a good relationship with his other mother (Tamimi, 2001:1-2).

To answer and explain the figure of Rachid Ghannouchi mentioned above, the theoretical framework that will be used in this paper is leadership theory. The leadership theory is used to find out about Rachid Ghannouchi's role as president of Tunisia after the Arab Spring in bridging two existing groups in Tunisia, namely Islamists and Secularists.

Leadership seems to be an experience-based concept which means that leadership can be found in a person from many practices or exercises. The concept of leadership is a fundamental component in analyzing processes and dynamics within the organization. For this reason, many studies and discussions that discussed the definition of leadership were confusing. According to Katz and Kahn (in Watkin, 1992) various definitions of leadership can basically be classified into three major groups namely "as an attribute or completeness of a position, as a person's characteristics, and as a category of behavior".

Leadership is the activity of people, which occurs between people, and is not something that is done for people so leadership involves followers. The leadership process also involves desires and intentions, active involvement between leaders and followers to achieve the desired goals together. Thus, both leaders and followers take personal responsibility to achieve these common goals (Hiebert, 2001: 4). In the definition of leadership included personal characteristics, behavior, and position of a person in a group. Based on this understanding, leadership theory is basically a study of individuals who have physical, mental, and position characteristics that are viewed more than other individuals in a group so that the individual concerned can influence other individuals in the group to act towards achieving a goal (Hiebert, 2001:8).

\section{LITERATURE REVIEWS}

After the Arab Spring, the studies have been carried out on the development of the situation of the Tunisian government. Starting from the trigger side, Revolution chronology, actors involved, the existence of political parties in Tunisia and the democratization process that has occurred two to five years since 2011. However, studies focusing on the role of a figure, especially Rachid Ghannouchi in bridging Islamists and secularists are still very limited especially in Indonesia.

First, the research from Sayida Ounissi (2016) member of the Tunisian Parliament from the Al-Nahdhah party, Ennahda From Within: Islamists or "Muslim Democrats"? This study was proposed as a refutation of the accusation of the Al-Nahdhah movement called Islamists. Ounissi's research focused on three things. First, further discuss the relationship of the Muslim Brotherhood as an inspiration for the Al-Nahdhah movement. Secondly, as a criticism of the failure of the "legalist" approach that predicts the future of the generation of the Egyptian Muslim Brotherhood, and the consequences for the Arab world. Ounissi also interpreted the 
real impact of the Egyptian coup on 3 July 2013 on Tunisia's transition. In the last part, the Ounissi study put forward a reinterpretation of the label of Islamists in the Al-Nahdhah party which according to him was inappropriate. For Ounissi, Al-Nahdhah deserves to be called a Muslim Democrat. In addition to focusing on these three things, Ounissi's research provides an overview of the roles of figures in Al-Nahdhah including Rachid Ghannouchi. However, researchers can see and utilize this Ounissi study to find out the role and strategy of Rachid Ghannouchi as the elected president in bridging the Islamists and Secularists.

Second, the writing of Noureddine Jebnoun (2014) an academic from the strategic study of the African Defense University. His writing is titled Tunisia at the Crossroads: An Interview with Sheikh Rachid Al-Ghannouchi. Jebnoun's writing is a collection of writings from the direct interview process he conducted with Rachid Ghannouchi. The interview provided information about Rachid Ghannouchi's brief biography, thoughts or views on Tunisia. In addition, the writings of Jebnoun also explained the birth of a movement in Tunisia initiated by Rachid Ghannouchi in 1979 when he founded Jamaat al-Islamiya in a political group. In Jebnoun's writings there is also Rachid Ghannouchi's optimism that Tunisia will be able to become a model for countries in the Arab world in implementing democracy by embracing many parties. From the writings of Jebnoun, which came from a direct interview with Rachid Ghannouchi, this could be used as a reference in understanding the role of Rachid Ghannouchi. On the other hand, in the writings of Jebnoun described the ideology and optimism of Rachid Ghannouchi which is the background of his policy in stabilizing the condition of Tunisia.

Third, Khaled Elgindy's research was published in The Arab Studies Journal (1995) entitled The Rhetoric of Rashid Ghannushi. Elgindy's writing describes the comparison of high ideals between two Tunisian figures, Ben Ali and Rachid Ghannouchi, which emphasized the role of Ghannouchi who has a leading vision, democratic attitude, and openminded openness towards the western world. In addition, according to Elgindy, Ghannouchi not only has political influence in Tunisia but also has a strong ideology and strategic tactics to improve the situation of Tunisia. Elgindy's research can be used as a reference for researchers because of the description of Rachid Ghannouchi's journey in politics.

Fourth, a thesis entitled Contemporary Islamic Thinkers' Understanding of Secularism (2014) written by Tobias Muller, student of the master of philosophy at Cambridge University. Muller's thesis reveals the gap in the analysis of the understanding of secularism in the minds of two Islamic thinkers namely Rachid Ghannouchi and Abdolkarim Soroush. Muller's thesis goes deeper into the postcolonial situation in understanding secularism, understanding secularism and democracy in the West, secularism and democracy in the Arab world, and The Islamic State which is ideal for the Arab world, of course from the views of Rachid Ghannouchi and Abdolkarim Soroush. This thesis becomes relevant as a reference for the author but for the author it will emphasize Rachid Ghannouchi's role in bridging Islamists and Secularists.

Based on the review of four journals, two theses, one book, and the writings of the interviews above, no one has specifically discussed the role of Rachid Ghannouchi in Democratization in Tunisia Post-Arab Spring in particular the characteristics or style of leadership. But from the literature review above the author can obtain a lot of information to compile and analyze the role of Rachid Ghannouchi in Democratization in Tunisia after the Ben Ali regime.

From this description, this research will answer and explain two things. First, Rachid Ghannouchi's efforts in democratization in Tunisia after the Arab Spring Revolution. Second, Rachid Ghannouchi's efforts to bridge Islamists and Secularists in Tunisia after the Arab 
Spring. The results of this study can be used as an illustration of the democratization and political Islam movement in the Middle East and a description of the success rate undertaken by Rachid Ghannouchi as a liaison between Islamists and secularists in the democratic transition in Tunisia.

\section{THE ROLE OF RACHID GHANNOUCHI}

In understanding one's leadership style, an understanding of the characteristics is needed. This also applies in this journal article which will describe Rachid Ghannouchi's role in democratization in Tunisia after the Ben Ali regime. The democratic transition that occurred in Tunisia after the Arab Spring was a transition that brought a major change, namely the transition of the country from dictatorship to a democratic state. This, of course, brought about a change in Tunisia, a democratic transition that affected the political stage and the life of civil society in Tunisia.

The transition in Tunisia made Rachid Ghannouchi take the role. The way taken by Rachid Ghannouchi is inseparable from the life experience in the form of the environment and the educational process that he passed, including the life experiences in Europe. At the age of sixteen, Ghannouchi grew up and lived with his maternal uncle, al-Bashir. Uncle Ghannouchi, al-Bashir was a fanatical supporter of Arabism and a big fan of President Nassir in Egypt. Ghannouchi has a good communication relationship with al-Bashir. This is evidenced by the discussion between the two about life to political analysis. In addition, al-Bashir always told about President Nassir and his lectures, especially about President Nassir's resistance to the West. On the other hand, al-Bashir also described President Nassir as a bikbashi or a great army leader. Starting from al-Bashir's explanation, Ghannouchi thought that President Nassir was a great character and could be a role model for him. During his uncle's time, Ghannouchi also knew the figure of Bourguiba who also opposed France before Tunisia gained independence (Tamimi, 2001: 5-6).

In 1959, eighteen-year-old Ghannouchi followed the eldest brother leaving the village to the capital to continue his education in the field of Arabic history at az-Zaytouna university and complete his education in 1962 (Tamimi, 2001: 9-10). During his stay in az-Zaytouna, Ghannouchi felt a contrasting situation in which the Islamic education received from his father and his educational environment were inversely proportional to the environment which was thick with secular conditions due to the influence of French colonization with the surrounding urban style and the consolidation of the Bourguiba regime. In Ghannouchi's mind the secularist term does not only refer to lifestyles that are limited by the role of religion but also the design of Western thought. In addition to learning about Arab history, Ghannouchi also studied philosophy and had an interest in issues in theory.

In addition, Rachid Ghannouchi's thoughts were also inseparable from his interest in having an interest in the field of literature. This is reflected in his fondness for reading literary works from various countries. Among them are novels from Russian writers such as Leo Tolstoy (1828-1910) entitled War and Peace, Maxim Gorky (1868-1936) entitled Mother, Fyodor Dostoyevsky (1821-1881) entitled Crime and Punishment. In addition to reading literary works from Russian writers, Ghannouchi also read the work of Irish writer Bernard Shaw, French writer Victor Hugo and American novelist Ernest Hemingway. Not only that, Ghannouchi also read literary works by Arabic writers such as Najib Mahfudz, Yusuf asSibaei, Muhammad Abdelhalim Abdullah, and Colin Suhail (Tamimi, 2001: 8).

Arab Spring not only gave birth to figures like Rachid Ghannouchi, but also gave birth to great figures with their own thoughts and leadership styles. One of them is Muhammad Mursi. 
However, when compared to Muhammad Mursi, Rachid Ghannouchi tends to be stable and able to maintain his position. Muhammad Mursi in a short time could be coup by the military for failing to make political compromises. Muhammad Mursi is an Egyptian Ikhwan alMuslim cadre who won power after Husni Mubarak's coup, must be willing to return to being a victim due to a failure to compromise with the military and other political elites. Muhammad Mursi was coup on July 3, 2013 night by Abdul Fattah As-Sisi. (Hamdan Basyar, 113).

\section{THROUGH THE AL-NAHDAH PARTY}

In the mid-1960s, in Bourguiba's time, the impasse of the political and economic roles of the ulamas began to become increasingly clear. Their land is controlled and taken over by the state in significant numbers. This then impacted the decisions of several Sheikhs in Zaytunah to leave Tunisia for another part of the Islamic world. Among these people was Rashid AlGhannouchi, who at that time was one of the leaders of the forerunner of the MTI (Mouvement de la Tendance Islamique) movement. After going to Egypt, Ghannouchi studied in Damascus, because he felt in accordance with the learning system there (Tamimi, 2001: 1423).

Seeing the potential for resistance to the government is increasingly clear, then at the blessing of the government, the association of the Koran was formed. restructuring the experiment of socialism that has been going on during the reign, and, as mentioned earlier, to stem the critical flow of unpopular policies on Islam in the context of the campaign for secularism, as well as to balance the rise of the left (Waltz 1986: 652).

In 1972, Rachid Ghannouchi established the Jama'ah Islamiyah as a forum for movement. 6 years later, in 1978, a combination of several Islamic associations formed a joint movement which they called the Islamic Renewal Movement. Furthermore, in 1979, Rachid Ghannouchi and Abdul Fattah Murru led the association and formalized themselves as the Islamic Tendency Movement (Mouvement de la Tendance Islamique) (aljazeera, 2014).

The result of the development of Rachid Ghannouchi's thoughts, parallel with internal debates between different factions within the party - such as the moderate wing of Muru or Salafist Khouja radicalism - has become one of the important factors in increasing AlNahdhah's moderation. The first thing done by Ghannouchi, on the issue of the nature of Tunisia. There has been a gradual change in the position of the Tunisian Islamic movement since the 1970s. Under the influence of the Muslim Brotherhood's militant ideology in the late 1960s and throughout the 1970s, the Al-Nahdhah movement can be said to subscribe directly to the vision of the creation of an Islamic state where the application of sharia law to all societies as a unity contained in the principle of monotheism is the main goal . In this vision, it can be concluded that there is no overlap in the elaboration between state and religious relations (Merone, 2013: 857).

However, since the 1980s, Rachid Ghannouchi has been thinking about the nature of the secular Tunisian state that has made Al-Nahdah progressively delay its vision of an Islamic state. This situation doesn't just happen. As a party that emerged through significant political contestation in the late 1980s, and the radical tendencies of some of its uncompromising members, Ghannouchi considered that this party had arrived at a point to support the creation of a civil state (Dawlah Al-Madaniyyah), and openly disseminated ideas that the preference to recognize religion as a principle of the party is purely based on the basis of member identity, and does not originate from regulations made by the party. Departing from that, then in the debate that occurred after the 2011 revolution, Rachid Ghannouchi through Al-Nahdah was able to compromise with secular groups in sentences that reflected the principle of the party. 
This principle then produces practical impacts taken by Al-Nahdah in a coalition strategy with secular groups that implicitly reject the religious agenda in its struggle (Merone, 2013: 863864).

Subsequent efforts to compromise in the constitution succeed in eliminating the suspicion of many parties of the inability of Al-Nahdah to maintain the secular heritage of Tunisia. For Al-Nahdah, the interpretation of the texts of muamalat and the space of choices obtained from ijtihad made with consideration of maslahat as its premise, is the best way in the process of policy formation without having to pawn the principles and ideology of the party. This was shown in the debate process at the constitutional council. At a time when most of the legislators of Al-Nahdah support the Shari'ah, Islam is used as a legal basis in the constitution, others, especially the left and secular groups, reject this legality by offering the concept of universal human rights as a constitutional preambule. Al-Nahdah finally accepted the concept in order to maintain the authority of the transitional government even though there was an internal upheaval in Al-Nahdah itself, but the big name Rachid Ghannouchi could be a facilitator for the meeting of the two poles (Merone, 2013: 868-869).

In addition, Rachid Ghannouchi came forward with persuasive efforts both oral and structural. In one interview with the Financial Times, Rachid Ghannouchi revealed his closeness to various groups after the 2011 revolution even before that, as an affirmation that he was not involved and had no interest in stemming the pace of opposition as the Ben Ali regime did. He said that the coalition led by Al-Nahdah would bring together political parties to jointly develop Tunisian politics without discriminating. Even since 2005, as he admitted, the togetherness of the various groups has raised the same issue of promoting freedom of opinion and guaranteeing the right of every party to appear in public and participate in elections.

Cross-Party Partnership \& Coalition-Building. Ghannouchi explicitly acknowledged the rights of any party, regardless of ideology and background, to govern if supported by the will of the people, in front of both Islamic and secular parties. Ghannouchi also promotes not only the principle of coexistence, but partnerships and joint work between parties regardless of intellectual or political background. Many examples of such interaction and partnership exist since the eighties, but perhaps one of the most prominent and effective examples is the 18 October Committee of 2005. The Committee, which brought together political activists, journalists, human rights activists from various parties as well as independents, began as a joint hunger strike on the occasion of the World Summit on the Information Society in Tunis to draw attention to the continuing deterioration of the state of freedoms in Tunisia and to call for ending human rights violations, lifting restrictions on liberties, and releasing political prisoners.

Ghannouchi thinks that the Committee then continued its joint activities and dialogue in order to elaborate a shared vision for a post-Ben Ali democratic Tunisia. It produced joint papers on important questions such as the equality of men and women, freedom of belief in a modern Muslim country and the relationship between religion and state in the future democratic system. The partnership between secular and Islamist activists was challenging, both intellectually and politically, since Ben Ali's regime was founded on division and polarization and fiercely opposed any such rapprochement. However, the partnership was very important, productive and fruitful, laying the ground for future partnership in struggling against dictatorship and in building democracy.

The collaboration was realized in the form of a coalition called the Troika coalition. The Troika coalition between Ennahdha and two secular parties was a clear proof of our conviction that Tunisia should only be governed through consensus, and that transitions 
cannot be managed by the logic of majority versus minority. In fact, the Tunisian political elite, and thanks to a great extent to Ennahdha's efforts, elaborated the concept of transitory democracy, which is based on participation and consensus-building rather than majoritarian democracy.

Al-Nahdah's figures, especially those conveyed by Rachid Ghannouchi, showed persuasive efforts to unite various groups that were divided after the revolution. At the tenth party congress moment, April 2016, Al-Ghannouchi, announced the separation of politics and religion and affirmed the status of Al-Nahdhah as a pure political party separate from religion, but inspired by religious attitudes as a function underlying the movement. Ghannouchi also stated that Al-Nahdhah was a party, open to all Tunisians and political figures in Tunisia. Furthermore, Rachid Ghannouchi emphasized:

"The first was a paper on political pluralism. There is no limit to political pluralism other than the condition of rejecting violence, and giving anyone the right to found the party. The second was the rights of women because the government used to always say to frighten people away that (the Islamists) will take away the rights of women to frighten people away. We had to reassure others in this coalition who were being accused of working with the Islamists. And we all recognise and accept the personal status code and will not cancel it or reject it. Indeed we have made this clear since 1988 on 17 July when I made a statement in which I recognised the personal status code."

This shows that Rachid Ghannouchi through his party, Al-Nahdah, tried to pursue a peaceful political process without trying to distort its relationship with other groups. In addition, Rachid Ghannouchi gave choices in the form of agreements which became a sensitive issue during the revolution. These issues include women's rights, political pluralism, issues of Islamization, although at a certain stage were rejected by a handful of radicals in $\mathrm{Al}$ Nahdah, Rachid Ghannouchi tried to create a party platform in building a peaceful political transition and embracing all parties. This was evident when Al-Nahdah accepted the defeat of Nidaa Tounis, a new party founded by a former old regime figure who also curbed Al-Nahdah in the 2014 parliamentary and presidential elections.

\section{CONCLUSION}

Rachid Ghannouchi's role in democratization in Tunisia after the Arab Spring did not originate from an instant but was motivated by the journey of Rachid Ghannouchi's life. In addition, the role of family members also greatly influenced Rachid Ghannouchi's thoughts and experiences of his life. Rachid Ghannouchi carried out his role as a 'bridge' for the two opposing groups in Tunisia through his thoughts which were carried out through the AlNahdah Party he led. The democratic transition that occurred in Tunisia after the Arab Spring was a transition that brought a major change, namely the transition of the country from dictatorship to a democratic state. This, of course, brought about a change in Tunisia, a democratic transition that affected the political stage and the life of civil society in Tunisia. What Rachid Ghannouchi did was trying to pursue a peaceful political process without trying to distort his relationship with other groups and give choices in the form of agreements that became sensitive issues during the revolution. These issues include women's rights, political pluralism, issues of Islamization and trying to create a party platform in building a peaceful political transition and embracing all parties. In addition Rachid Ghannouchi also conducted Cross-Party Partnership \& Coalition-Building. Ghannouchi explicitly acknowledged the rights of any party, regardless of ideology and background, to govern if supported by the will of the people, in front of both Islamic and secular parties. 


\section{ACKNOWLEDGEMENT}

This research based on grant scheme of PITTA (Publikasi International Terindeks untuk Tugas Akhir) or also known as Indexed International Publications for Final Projects toward Universitas Indonesia students. Thank you to Dr. Muhammad Luthfi as my advisor.

\section{REFERENCE}

[1]. Aarts, Paul. dkk. (2012). From Resilience to Revolt: Making Sense of The Arab Spring. Amsterdam: University of Amsterdam.

[2]. Boulby, Marion. 1988. The Islamic Challenge: Tunisia since Independence. Third World Quarterly, Volume. 10, No. 2, Islam \& Politics, April 1988.

[3]. Elgindy, Khaled. 1995. The Rhetoric of Rashid Ghannushi. The Arab Studies Journal, Vol. 3, No. 1 (Spring), page 101-119. Diakses pada 11 Februari 2018 pukul 10.36 melalui jstor.org.

[4]. Fraihat, Ibrahim. 2016. Unfinished Revolution Yemen, Libya, Tunisia. London: Yale University Press.

[5]. Hiebert, Murray dan Bruce Klatt. 2001. The Encyclopedia Of Leadership A Practical Guide To Popular Leadership Theories And Techniques. New York: The McGraw-Hill Companies.

[6]. Jebnoun, Noureddine. 2014. Tunisia at the Crossroads: An Interview with Syeikh Rachid al-Ghannouchi. Amerika: Alwaleed Bin Talal Center for Muslim-Christian Understanding Georgetown University.

[7]. Kartini, Indriana dkk. 2016. Agama dan Demokrasi: Munculnya Kekuatan Politik Islam di Tunisia, Mesir, dan Libya. Bandung: PT. Dunia Pustaka Jaya.

[8]. Kuncahyono, Trias. 2013. Musim Semi di Suriah. Jakarta: Penerbit Kompas.

[9]. Merone, Fabio \& Francesco Cavatorta. Moderation through exclusion? The journey of the Tunisian Ennahda from fundamentalist to conservative party. Journal of Democratization, Volume.20, No.5, 2013.

[10]. Muller, Tobias. 2014. Contemporary Islamic Thinkers's Understanding of Secularism. Inggris: University of Cambridge.

[11]. Nachi, Mohamed. 2016. Transition to Democracy in Tunisia: Learning About Citizenship in a National and Transnational Context. Social Science Information, Vol. 55(4) 429-445.

[12]. Nelson, Harold D. 1987. Tunisia: A Country Study. Washington D.C: The American University.

[13]. Ounissi, Sayida. 2016. Enahda from within: Islamism or "Muslim Democrats"?. Massachusetts: Brookings Institution.

[14]. R. Saoud. 2004. The Impact of Islam on Urban Development in North Africa. Manchester: Foundation of Science Technology and Civilization.

[15]. Ramahan, Tariq. (2012). Islam And The Arab Awakening. London: Oxford Press

[16]. Tais, . M. Amine. Islamic Perspectives in Post-revolutionary Tunisia; The Work of Olfa Youssef. Journal of Religion and Society. Volume. 17.

[17]. Tamimi, Azzam. S. 2001. Rachid Ghanouchi: A Democrat Within Islamism. Inggris: Oxford University Press

[18]. Taqwa, Libasut. 2016. Peran Partai Al-Nahdhah dalam Rekonsiliasi Politik di Tunisia Tahun 2011-2015. Jakarta: Universitas Indonesia (Tidak dipublikasikan). 
[19]. Watkins, Peter. (1992). A Critical Review of Leadership Concpets and Research: The Implication for Educational Administration. Geelong: Deakin University Press.

[20]. Zada, Khamami. 2015. Gelombang Revolusi dan Transisi Politik di Timur Tengah dan Afrika Utara. Salam: Jurnal Sosial dan Budaya Syar"ei. Vol. 2 No. 1 Juni.

[21]. http://www.aljazeera.net/encyclopedia/movementsandparties/2014/6/ 24 . Diakses pada 9 April 2018

[22]. https://www.ft.com/content/24d710a6-22ee-11e0-ad0b-00144feab49a, diakses pada 24 April 2018

[23]. http://www.wipo.int/edocs/lexdocs/laws/en/tn/tn028en.pdf. diakses pada 1 April 2018.

[24]. http://tunisiatn.com/ennahdas-shift-from-political-islam-to-muslim-democracy-atcenter-of-10th-party-congress/ diakses pada 24 April 2018

[25]. http://www.middleeasteye.net/news/rached-ghannouchi-interview-2016275498 diakses pada 24 April 2018

[26]. http://english.religion.info/2015/03/24/tunisia-islamists-in-fragile-democracyinterview-with-rashidghannouchi/ diakses pada 24 April 2018

[27]. https://www.washingtonpost.com/opinions/an-interview-with-tunisias-rachidghannouchi-three-years-after-therevolution/2013/12/12/7aaaaa5a-62cf-11e3-a3730f9f2d1c2b61_story.html?utm_term=.9e43cebdb6b8 diakses pada 24 April 2018

[28]. http://www.aljazeera.com/news/africa/2011/02/2011233464273624.html semua diakses pada 24 April 2018

[29]. http://www.arabstates.undp.org/content/dam/rbas/doc/Compendium\%20English/Part\% 202/14\%20Rached\%20Ghannouchi\%20EN.pdf diakses pada 1 April 2018 